\title{
Pharmacotherapy versus psychological interventions in recurrent abdominal pain: in light of new evidence
}

\author{
Bezsheiko Vitaliy ${ }^{1 \mathrm{a}}$ \\ ${ }^{a}$ Bogomolets National Medical University, Kyiv, Ukraine
}

\begin{abstract}
Background. Chronic or recurrent abdominal pain is a relevant problem, which affects more than $15 \%$ of children, adolescents and young people. Organic reason for this pain can't be found in most cases. Recently published studies have questioned the traditional treatment schema with prescribing antispasmodics, antidepressants and other traditional drugs and shifted focus towards psychological interventions.
\end{abstract}

Keywords: pain, abdominal, irritable bowel syndrome, pharmacotherapy, psychotherapy, Cochrane, psychological interventions, functional dyspepsia, abdominal migrane, recurrent abdominal pain, children, adolescents, young people, functional, disorders

\section{1. Актуальність}

Гострий та хронічний біль $є$ найбільш частою скаргою пацієнтів, які звертаються за допомогою до сімейних лікарів та дільничних терапевтів $[<1>]$. Одним із частих видів болю відповідно до локалізаціє є біль у абдомінальній ділянці. Згідно із прийнятими дефініціями хронічний (рекурентний) абдомінальний біль констатується при наявності больових відчуттів як мінімум 4 рази на місяць протягом останніх 2 місяців $[<2>]$.

Найбільш актуальною ця проблема $є$ серед дітей,

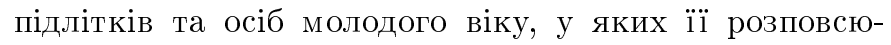
дженість коливається в межах 5-25\% $[<3>]$. Важливо зазначити, що більшість випадків хронічного болю у животі не спричинені органічними змінами чи соматичними захворюваннями. Так, у дослідженні, проведеному в Норвегії серед дітей із цим больовим синдромом, 93\% мали біль у животі функціонального генезу, iз них $87 \%$ повністю відповідали діагностичним критеріям функціональних шлунково-кишкових розладів. При цьому найбільш розповсюдженим був синдром подразненого кишківника $(\mathrm{C \Pi K})-43 \%[<4>](1)$.

Зазвичай діагноз рекуретний абдомінальний біль у Європі та США ставлять дітям та молодим людям. $\mathrm{y}$ дорослому віці цей діагноз трансформується у синдром подразненого кишківника (CПK) чи інший функціональний розлад за MKX-10. Серед дорослих СПК
Рис. 1: Структура абдомінального болю неорганічного генезу у дітей та підлітків.

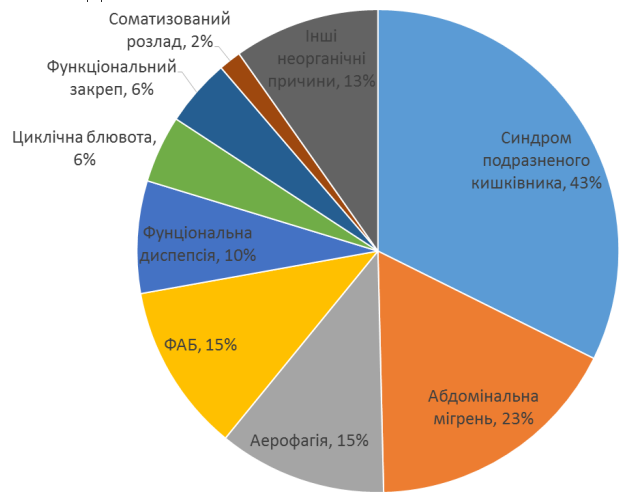

Серед 142 обстежених дітей шкільного віку із рекурентним болем в животі $93 \%$ мали функціональні порушення, структура яких представлені на діаграмі. Найбільш поширеними були синдром подразненого кишківника, абдомінальна мігрень, аерофагія та ФАБ (функціональний абдомінальний біль). До категорії «Інші» віднесено стани неорганічної етіології, які не підпадають під діагностичні критерії жодного функціонального порушення. 
діагностується приблизно у 5-11\% загальної популяції $[<\underline{5}>;<\underline{6}>]$. Незважаючи на те, що цей стан не асоційований із підвищеною смертністю, він значно знижує працездатність та якість життя пацієнтів.

Сучасні знання стосовно етіології функціонального болю грунтуються на експериментах 3 дослідження впливу стресу на організм на тваринних моделях. Психологічний стрес сприяє активації лімбічної системи та паравентрикулярних ядер гіпоталамусу. Це призводить до зниження продукції окситоцину та кортикотропіну. Зниження концентрації окситоцину та адренокортикотропного гормону у гіпофізі, в свою чергу, знижує рівень кортизолу у наднирниках та стимулює активність вагусної активності у кишківнику через гаммаеферентні нервові волокна ретикулоспінального тракту в м'язах. Це призводить до неприємних та больових відчуттів у абдомінальний ділянці $[<7>]$.

Враховуючи цей механізм, первинним лікуванням у більшості випадків мала би бути психологічна допомога, наприклад, стрес-менеджмент, вироблення нових копінг стратегій боротьби за стресом, релаксація чи інші подібні методи. Однак на практиці таким пацієнтам частіше призначають препарати, які не мають прямого впливу на патогенез цього функціонального болю. В Україні це зазвичай спазмолітичні препарати, антирефлюксні засоби (якщо на перший план виходять диспептичні симптоми), атипові нейролептики (сульпірид) та великий перелік БАДів, закордоном це також антидепресанти, антигістамінні та проносні засоби. Яка ж доказова база для цих двох підходів? Нижче наведені результати порівняно нещодавно опублікованих досліджень, в яких основну вибірку склали діти та молоді люди.

\section{2. Лікування рекурентного абдомінального бо- лю}

\section{1. Психологічні інтервениї}

Рекурентний абдомінальний біль (РАБ) - об'єднуюча назва для всіх типів порушень із больовим синдром у абдомінальній ділянці неорганічної етіології у дітей та молодих людей. Нещодавній Кокранівській систематичний огляд, який досліджував ефективність психологічних інтервенції при цьому розладі у дітей та підлітків, наробив чимало галасу у медичній спільноті $[<8>]$. В ньому було чітко продемонстровано ефективність психологічної допомоги при РАБ.

Як відомо, Кокранівські систематичні огляди проводяться групами незалежних експертів, які не мають конфлікту інтересів з приводу теми дослідження. В ньому проводиться аналіз всіх якісних рандомізованих контрольованих досліджень, в якому всі отримані в них результати приводяться до спільного знаменника за допомогою мета-аналітичних методів. На основі цих систематичних оглядів, створюються відповідні клінічні настанови.
Достатньо якісними для включення до аналізу були дослідження, присвячені оцінці ефективності когнітивно-поведінкової терапії (переважно сімейна), гіпнотерапія та йоги. Для порівняння слугували пацієнти, які отримували звичайне лікування (фармпрепарати) або чекали на лікування (так званий «waitlist»). Первинною кінцевою точкою, тобто показник, на який була спрямована найбільша статистична потужність аналізу, була успішність лікування, тобто суттєве зниження інтенсивності та частоти нападів болю після лікування у порівнянні з тим, що було до лікування ( $80 \%$ за шкалами, які оцінюють цей показник, або повна відсутність).

Аналіз виявив, що ймовірність успішності лікування в групах, які проходили когнітивно-поведінкову терапію (КПТ) була в 5,67 разів вища, ніж в контрольних групах. Ці дані базувалися на результатах 4x досліджень. Ймовірність успішності лікування для гіпнотерапії була в 6,78 разі вища у порівнянні із контрольними групами. Ці дані базувалися на аналізі 3x досліджень. Для йоги вдалося вирахувати тільки «стандартизоване відхилення» для інтенсивності болі. Цей показник в групах, які займалися йогою, у порівнянні 3 контролем був на 0,31 пункту нижчий, що відображає малу відмінність між цими групами $[<8>](1)$.

$\mathrm{y}$ висновках автори систематичного огляду зазначили, що гіпнотерапія та КПТ можуть бути ефективними для зниження РАБ як у короткочасній, так і у довготривалій перспективі. Однак якість доказів залишається низькою через невелику статистичну потужність досліджень.

Наразі психологічна допомога при функціональному болю у животі інтенсивно вивчається в рамках нових досліджень. Зазвичай КПТ інтервенції направлені на навчання справлятись із больовими відчуття через техніки відволікання, релаксації, виробленням копінгстратегій боротьби зі стресом, зміни негативних думок, пов'язаних із болем, та зміни відповіді членів родини на хворобу та поведінку пацієнта, асоційовану із хворобою. В той же час, гіпнотерапія зазвичай включає техніки навіюваної релаксації, входження у транс та керовану уяву (guided imaginary) як на сеансах, так i дома під час прослуховування попередньо зроблених аудіозаписів.

\section{2. Фармакологічні інтервениї}

Серед фармакологічних методів в рамках Кокранівського систематичного огляду вивчалась лише ефективність антидепресантів при функціональних кишково-шлункових розладах у дітей та молодих людей. Проаналізувавши дані всіх доступних досліджень, автори прийшли до наступних висновків $[<\underline{9}>]$ :

1. Лікарі повинні усвідомлювати, що більшість антидепресантів не мають доказової бази щодо лікування таких порушень. 
Табл. 1: Порівняння ефективності психологічної допомоги із контролем (звичайна допомога або відсутність лікування) при болі у животі неорганічного генезу в рамках Кокранівського огляду (modif. [8]).

\begin{tabular}{|c|c|c|}
\hline Показник та метод лікування & $\begin{array}{c}\text { Ймовірність досягнення у } \\
\text { порівнянні із контролем }\end{array}$ & Коментар \\
\hline \hline КПТ, успішність лікування & BР $5,67^{*}$ & $\begin{array}{c}\text { Суттєве зниження інтенсивності та } \\
\text { частоти болю або його повна } \\
\text { відсутність }\end{array}$ \\
\hline КПТ, якість життя & CВ $0,71^{*}$ & $\begin{array}{c}\text { Фізичний компонент якості життя, } \\
0,71-\text { відповідає середній величині } \\
\text { ефекту }\end{array}$ \\
\hline Гіпнотерапія, успішність лікування & ВР 6,78 & $\begin{array}{c}\text { Зниження інтенсивності болю } \\
\text { на 80\% }\end{array}$ \\
\hline Гіпнотерапія, частота болю & СВ 1,28 & $\begin{array}{c}\text { Відповідає великому розміру ефекту } \\
\text { в порівнянні з контролем }\end{array}$ \\
\hline Йога, інтенсивність болю & СВ 0,31 & Відповідає малому розміру ефекту \\
\hline \hline
\end{tabular}

* ВР - відносний ризик, тобто у скільки разів ймовірність досягнення результату більша, ніж в контрольній групі, СВ стандартизоване відхилення, тобто різниця між експериментальною групою та групою контролю по показнику, виражена в одиницях стандартного відхилення, де 0-0,2 - означає відсутність різниці, 0,2-0,5 - малу різницю (або малий розмір ефекту), 0,5-0,8 - середній розмір ефекту та 0,8 - великий розмір ефекту.

2. Єдиний антидепресант, стосовно якого вдалось зібрати достатньо даних для повноцінного аналізу, - амітриптилін, - не продемонстрував жодних переваг у лікуванні при порівнянні із плацебо. Ймовірність досягнення успіху при лікуванні амітриптиліном була лише на $12 \%$ вища, ніж у плацебо. Окрім того, різниця в покращенні стану між групами була статистично недостовірна.

3. При цьому, прийом антидепресантів при цих станах був асоційований із суттєвим підвищенням ризику побічних ефектів, які «перекреслювали» всі потенційно можливі переваги такого лікування, особливо це стосується лікування дітей.

Ще один із порівняно нещодавніх систематичних оглядів, який був проведений в 2015 році, також не продемонстрував значних переваг при використанні фармакотерапії у лікуванні абдомінального больового синдрому $[<10>]$. Автори зазначили наднизьку якість опублікованих досліджень. У порівнянні із плацебо певну ефективність у зниженні інтенсивності та частоти болю мала олія перцевої м'яти із групи спазмолітиків (ймовірність покращення в 3,3 рази вища ніж у плацебо) та ципрогептадин із групи антигістамінних засобів (тільки частота болю, ймовірність зниження у 2,43 рази вища, ніж у плацебо).

Недоліком дослідження единого дослідження, в якому вивчали ефективність олії м'яти перцевої, було те, що в ньому автори не зазначили, як саме вони оцінювали інтенсивність болю $[<11>]$. Недоліком единого дослідження по ефективності ципрогептадину був малий розмір вибірки (27 осіб) $[<12>]$.

Також певну ефективність, в рамках низької якості дослідження, продемонстрував експериментальний проносний препарат. Ймовірність значного зниження болю при його використанні була в 3,6 разів вище, ніж у плацебо. Антирефлюксні препарати, антидепресанти, препарати із інших груп та інші спазмолітичні, проносні і антигістамінні засоби не продемонстрували статистично значимого ефекту по відношенню до болю у порівнянні із плацебо.

\section{3. Висновки}

Таким чином, на сьогодення існує доволі невелика доказова база щодо лікування абдомінального болю неорганічної природи. Ефективність КПТ була продемонстрована в рамках $4 \mathrm{x}$ рандомізованих контрольованих досліджень, якість яких була достатня для включення в аналіз в рамках Кокраніського систематичного огляду. Ефективність гіпнотерапії - в 3х. Доказова база щодо фармакотерапії знаходиться на ще більш низькому рівні. Лише одиничні дослідження дуже низької якості демонструють зниження болю при використанні амітриптиліну (антидепресант), ципрогептадину (антигістамінний засіб) та олії м'яти перцевої (спазмолітик). Тема лікування рекурентного абдомінального болю потребує подальшого вивчення, але у світлі доступних доказів, на сьогоднішній день, перевагу слід надавати психологічним інтервенціям.

\section{References}

1. Nahin R. Estimates of pain prevalence and severity in adults: United states, 2012. The Journal of Pain 2015-aug;16(8):76980. doi 10.1016/j.jpain.2015.05.002

2. Hyman P. Chronic and recurrent abdominal pain. Pediatrics in Review 2016-sep;37(9):377-90. URL: http://dl.umsu.ac.ir/bitstream/Hannan/125309/1/2016\% 20PIR $\% 2$ Volume $\% 2037 \% 20$ Is sue $\% 209 \% 20$ September $\% 20(3)$.pdf 
3. Chitkara D, Rawat D, Talley N. The epidemiology of childhood recurrent abdominal pain in western countries: A systematic review. The American Journal of Gastroenterology 2005aug;100(8):1868-75. doi $10.1111 / \mathrm{j} .1572-0241.2005 .41893 . \mathrm{x}$

4. Helgeland H, Flagstad G, Grøtta J, Vandvik P, Kristensen H, Markestad T. Diagnosing pediatric functional abdominal pain in children (4-15 years old) according to the rome iii criteria: Results from a norwegian prospective study. Journal of Pediatric Gastroenterology and Nutrition 2009-sep;49(3):30915. doi 10.1097/MPG.0b013e31818de3ab

5. Krogsgaard L, Engsbro A, Bytzer P. The epidemiology of irritable bowel syndrome in denmark. a population-based survey in adults $\leq 50$ years of age. Scandinavian Journal of Gastroenterology 2013-mar;48:523-9. doi 10.3109/00365521. 2013.775328

6. Canavan C, West J, Card T. The epidemiology of irritable bowel syndrome. Clinical Epidemiology 2014-feb;6:71-80. doi 10. 2147/CLEP.S40245

7. Joychan S, Kazi R, Patel D. Psychosomatic pain in children and adolescents. J Pain Manage 2016;9(2):155-60.

8. Abbot R, Martin A, Newlove-Delgado T, Bethel A, ThompsonCoon J, Whear R, Logan S. Psychosocial interventions for recurrent abdominal pain in childhood. Cochrane Database of Systematic Reviews 2017;(1). doi 10.1002/14651858. CD010971. pub2

9. Kaminski A, Kamper A, Thaler K, Chapman A, Gartlehner G. Antidepressants for the treatment of abdominal pain-related functional gastrointestinal disorders in children and adolescents. Cochrane Database of Systematic Reviews 2011;(7). doi 10. 1002/14651858.CD008013.pub2

10. Korterink J, Rutten J, Venmans L, Benninga M, Tabbers M. Pharmacologic treatment in pediatric functional abdominal pain disorders: A systematic review. The Journal of Pediatrics 2015-feb;166(2):424-31. doi 10.1016/j.jpeds.2014.09.067.

11. Kline R, Kline J, Palma J, Barbero G. Enteric-coated, phdependent peppermint oil capsules for the treatment of irritable bowel syndrome in children. The Journal of Pediatrics 2001jan;138(1):125-8. doi 10.1067/mpd.2001.109606

12. Sadeghian M, Farahmand F, Fallahi G, Abbasi A. Cyproheptadine for the treatment of functional abdominal pain in childhood: A double-blinded randomized placebo-controlled trial. Minerva Pediatrica 2008;60(6):1367-74. 